\title{
New Petro-Mineralogical Results on the Magmatic Surrounding Rocks of Cu-Ag Mineralization in Tagmout (Eastern Anti -Atlas, Morocco)
}

\author{
Moussaid Azizi, \\ Aissa Mohamed, \\ Moulay Ismail University Faculty of Science, \\ Department of geology PB 11201 Zitoune Meknes Morrocco \\ El Azmi Mohammed, \\ Managem / ONA. Center, Tower A, PB 16016, \\ Mâarif Casablanca, Morocco \\ Souiri Muhamed, \\ Mezougane Hafid, \\ Moulay Ismail University Faculty of Science, \\ Department of geology PB 11201 Zitoune Meknes Morrocco \\ Kharis Abdel-ali, \\ Zouhair Mohamed, \\ Managem / ONA. Center, Tower A, PB 16016, \\ Mâarif Casablanca, Morocco
}

Doi: 10.19044/esj.2017.v13n36p368 URL:http://dx.doi.org/10.19044/esj.2017.v13n36p368

\begin{abstract}
Tagmout deposit is located in the Eastern Anti-Atlas, about $30 \mathrm{~km}$ south of the city of Qalâat Mgouna. It contains $\mathrm{Cu}-\mathrm{Ag}$ mineralization which is embedded in magmatic rocks that are essentially intrusive of various facies. Detailed mapping (1/1200) and petro-mineralogical observation of these facies allow us to distinguish: 1) Olivine gabronorite, it is composed mainly of pyroxenes (CPX and OPX), olivine and biotite; 2) Quartz monzogabbro, it is characterized by the presence of pyroxenes, amphiboles, plagioclases, FK and quartz; 3) Quartz monzodiorite, which is a porphyric facies. It occupies the center of the Tagmout sector which is rich in FK, plagioclase, quartz, amphibole and pyroxene; 4) Granodiorite, it is a facies associated with quartz monzodiorite. It shows a paragenesis composed of FK, quartz and plagioclase; 5) Pink microgranite, metric dykes developing in different directions $\left(\mathrm{N} 10^{\circ}\right.$ to $\mathrm{N} 15^{\circ}, \mathrm{N} 70^{\circ}$ to $\mathrm{N} 90^{\circ}, \mathrm{N} 120^{\circ}$ to $\left.\mathrm{N} 130^{\circ}\right)$. It is a facies rich in quartz, FK and plagioclase; 6) Dolerite, It is a dark-colored facies with a typical doleritic texture. It is rich in plagioclase and relics of
\end{abstract}


pyroxenes and amphiboles. This facies occupies the eastern part of Tagmout complex; 7) Volcano-sedimentary facies with rhyolite appearance of brick red color. It is a vitreous fine matrix and conglomerate elements which is rich in quartz and FK. These are conglomerates that are affected by the terminal neoproterozoic rhyolitic lavas. They are also affected to different degrees by several phases of hydrothermal alterations of potassic, phyllitic, clayey, and propylitic types. The effect of these alterations on the rock at the surface is very variable. The granodiorite is highly affected while olivine gabbronorite is not very sensitive and retains a remarkable state of freshness. This raises an interrogation on the chronological place and the advanced age for these facies (557 $\pm 5 \mathrm{Ma}$, Benziane and al. 2008).With the exception of recent formations (microgranite, dolerite and volcano-sedimentary facies), the contact between the plutonic rocks of Tagmout (olivine gabbronorite, quartz monzogabbro, quartz monzodiorite, granodiorite and granite) never takes major structural discontinuity nor contact metamorphism. But the localization of some enclaves on both sides of the neighboring facies with an intense brecciation marked the contact of these facies. This configuration suggests that the plutonic formations of Tagmout massive that the setting up was done in a contemporary way and is derived from the same magma by fractional crystallization in a magmatic chamber.

Keywords: Anti-Atlas, Tagmout, magmatic rocks, petro-mineralogy.

\section{Introduction}

Tagmout massive is located in the heart of Central Saghro. It is located approximately $30 \mathrm{~km}$ south of the city of Qalâat Mgouna (Province of Ouarzazate). It is located on the topographical map 1/50000 of Qalâat Mgouna (fig.1).

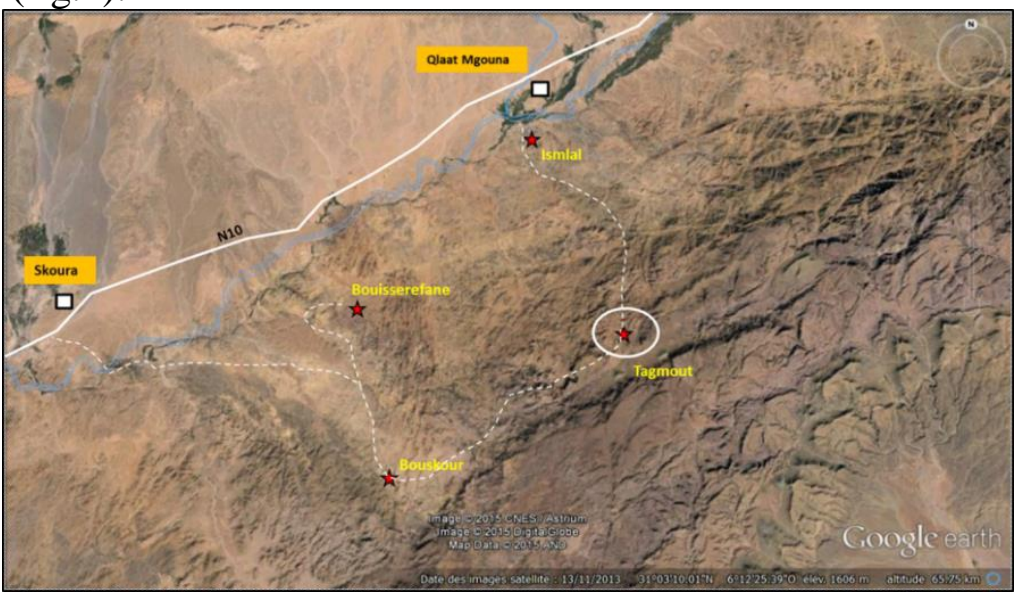

Figure 1: Geographical location of Tagmout massive. 


\section{History of work}

In spite of the numerous research works affecting the different units of the Eastern Anti-Atlas particularly Jbel Saghro due to research of mineral resources, the study of the Tagmout zone was completely ignored except for a geochemical study carried out on the basic massive and its relationship with the associated granitoids by Mokhtari (1993).

\section{Geological setting}

Regionally, Tagmout massive belongs to the Eastern Anti-Atlas on the southern edge of Jbel Saghro range and on the northern boundary of a large graben oriented NE-SE (Graben of Tagmout). This chain corresponds to all the reliefs between the pre-African furrow to the north and the Major Anti-Atlasic Accident to the south. It is spread over an area of nearly 4000 $\mathrm{km} 2$ with a NE-SW general direction constituting thus the largest inlier of the Anti-Atlas. It is bounded north by the valley of Dades, east by the massive of Ougnat and Tafilalet, west by the valley of Drâa and the inlier of Bou Azzer and South by Jbel Bani (Fig. 3).

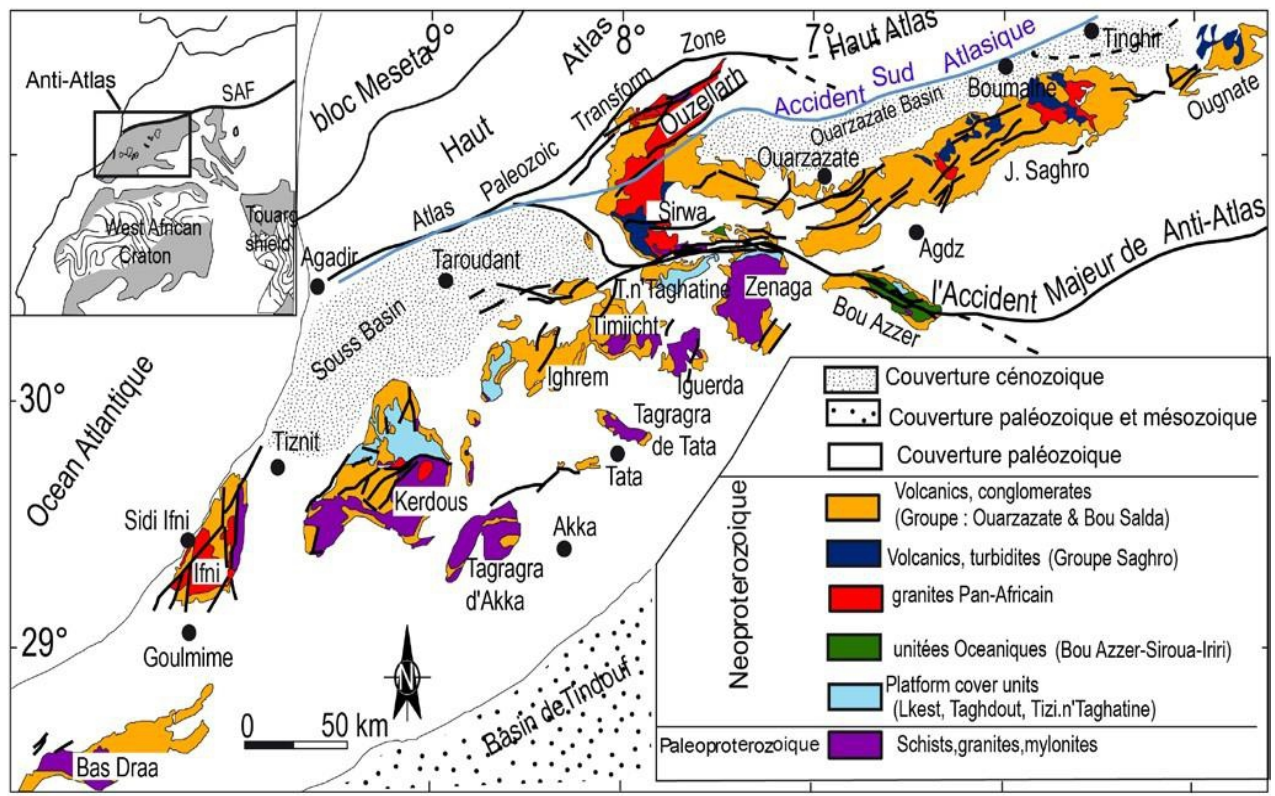

Figure -2: Geological map of the Anti-Atlas, (Gasquet and al. (2008)).

Geologically, this is a lower cryogenic base which is outlined in four areas that will also be defined as smaller inliers from west to east: Sidi FlahBou Skour, Tagmout, Kelâat Mgouna, Boumalne and Imiter. The formations of the base are covered by thick series of the upper cryogenic of the Ediacarian and the Adoudounian. 
Locally, Tagmout massive is hosted in magmatic formations occupying the center of Saghro. Our mapping work targeted the largest district of Tagmout deposit. The result is the elaboration of a detailed geological map (1/1200) (Fig. 3).

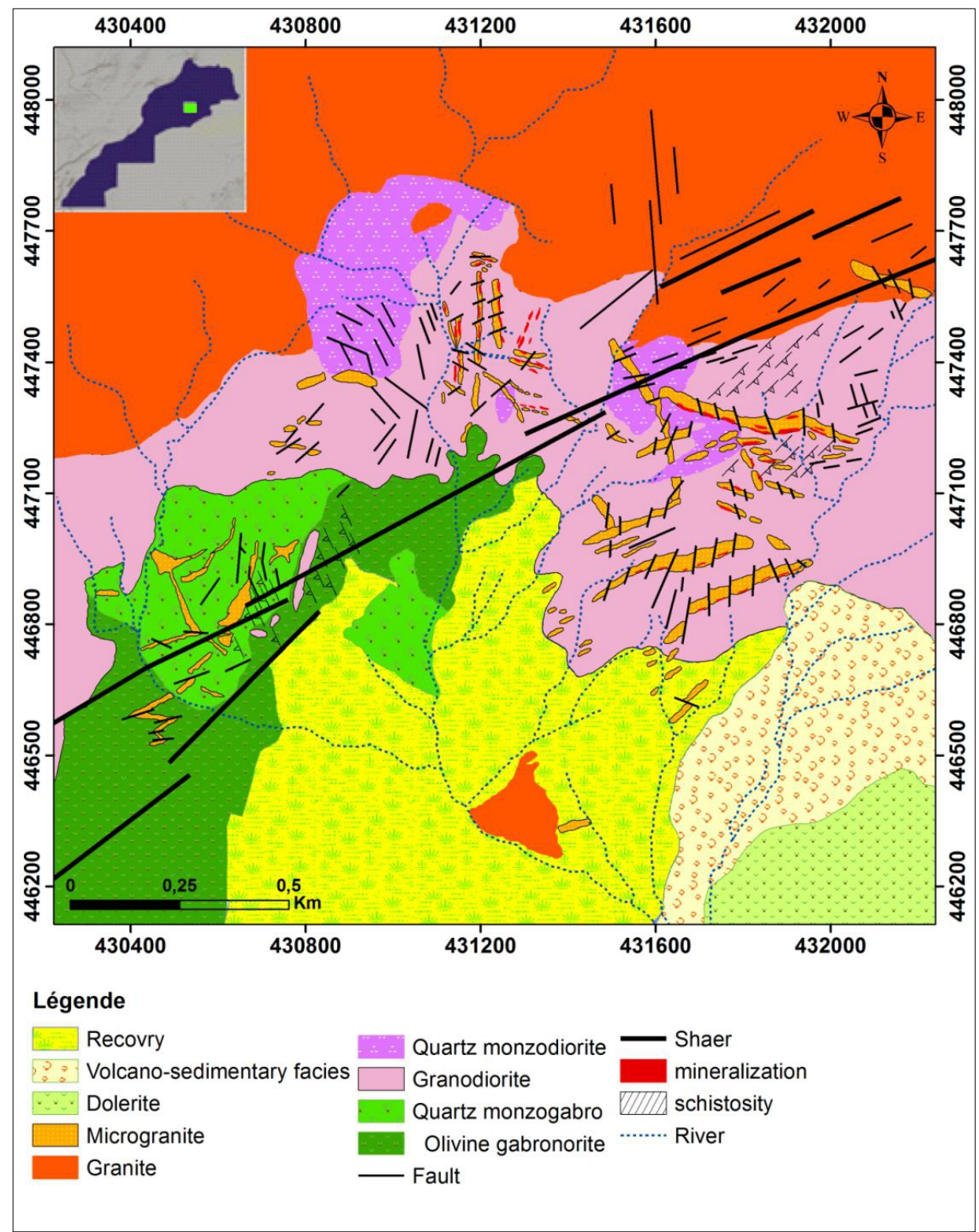

Fig. 3: Geological map of Tagmout.

\& 
Several facies have been distinguished:

1. Olivine Gabbronorite: This is a basic plutonic facies with a less or more grained and well crystallized texture that is flushing in the massive at the center and the west of the study area. These rocks are traversed by microgranite dykes. (Fig. 4, Photos B, D and E);

2. Quartz Monzogabbro: This facies occupies the central part of the gabbroic massive (Fig. 4). This is a facies with mesocratic color and a grainy texture. On the ground, this facies undergoes an alteration in a ball. In place, the rock disintegrates into granite arena;

3. Quartz Monzodiorite: It is a rock with a porphyric texture and a mesocratic color. With the naked eye, we can distinguish most of the minerals from their paragenesis. An important alteration attacks this rock because of its coarse texture (Fig. 4, Photos C and F).

4. Granodiorite: It is an intermediate intrusive magmatic rock that occupies the upper part of the study area. It is widely altered by a circulation of hydrothermal fluid. This facies is cut by the microgranite dykes (Fig. 4, Photo A).

5. Granite: it occupies the uppermost part of the massive. It shows a coarse texture and an intense alteration.

6. Microgranite: Regionally, they are numerous. In the field, they can be confused with the rhyolite dykes which take the same pink color and which are often with the same orientations. They can be subdivided into graphic quartz microgranite, microgranite with tourmaline, muscovite microgranite and porphyritic microgranite. The microgranite of Tagmout is presented on the ground in metric dyke with a pink color. They are affected by the synthetic faults drawing an appearance of the graben (Fig. 4, Photo C). On the ground it presents itself with different directions.

7. Dolerite: It is a volcanic facies of a dark color and a thin microlitic texture. This facies is manifested regionally in dykes cutting the different facies (pink granite of Iskn'Alla, wachich granite, black rhyolitic tuffs ...). In the field, the dolerites of the Tagmout crop out in mass with important size. They are concentrated at the extreme end of the eastern part of the study area (see geological map).

8. Volcano-sedimentary facies: This facies corresponds to conglomerates and sandstones that are interstratified by volcanic flows.

At Tagmout, the conglomerates and sandstones are stratified in the rhyolitic lavas. Their power does not exceed four meters thick. It is a chocolate red rhyolitic appearance facies with a very fine matrix of volcanic nature. The figured elements are of different sizes and correspond to the residues of conglomerates and red sandstones. 
With the exception of recent formations (microgranite, dolerite and volcano-sedimentary facies), the contact between the plutonic rocks of Tagmout (olivine gabbronorite, quartz monzogabbro, quartz monzodiorite, granodiorite and granite) never takes major structural discontinuity nor contact metamorphism. But the localization of some enclaves on both sides of the neighboring facies with an intense brecciation marked the contact of these facies. This configuration suggests that the plutonic formations of Tagmout massive that the setting up was done in a contemporary way and is derived from the same magma by fractional crystallization in a magmatic chamber .

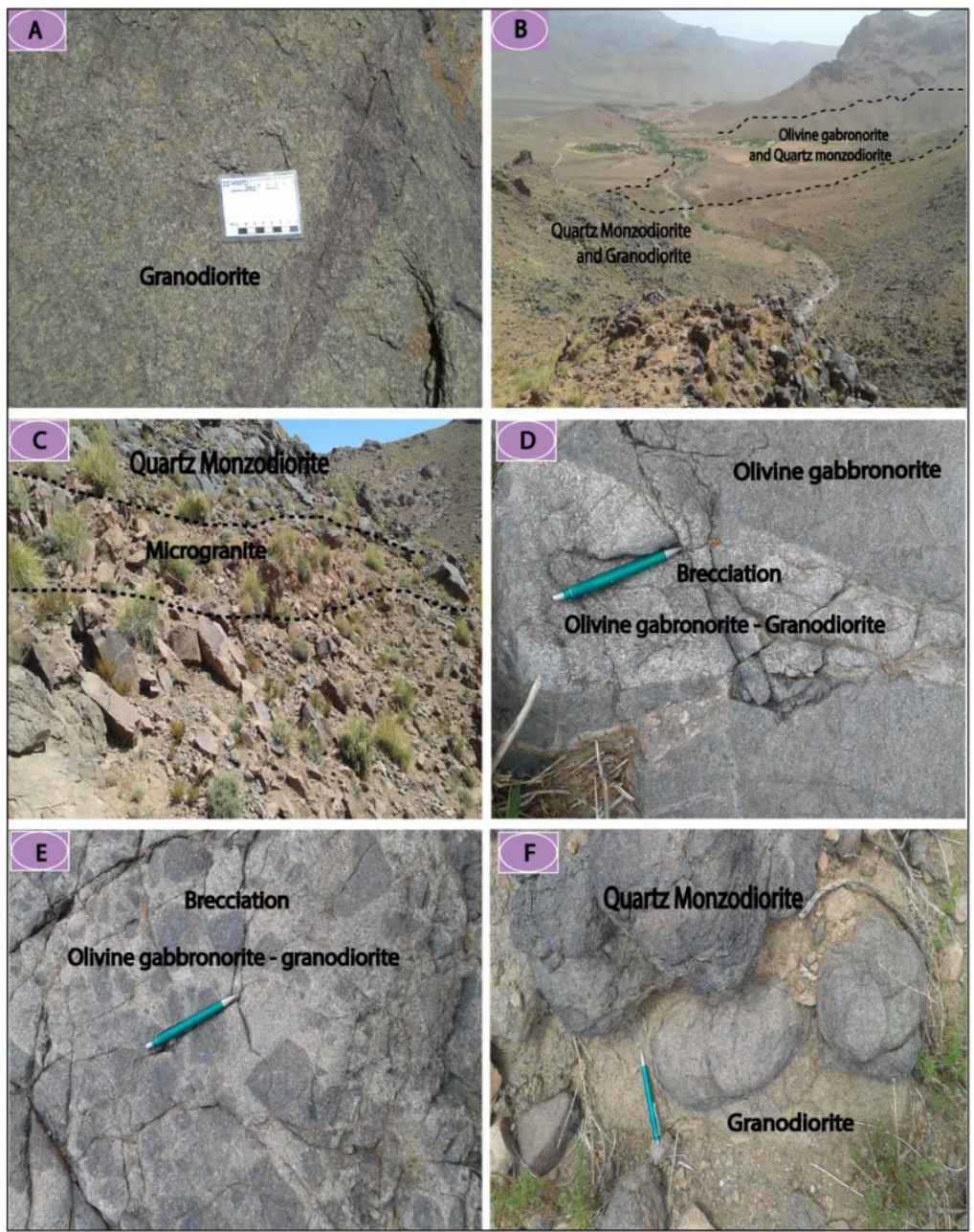

Fig. 4: photos showing the different geological rocks of Tagmout. 


\section{Petrographic analysis.}

The petrographic study is based on macroscopic and microscopic observations of the representative samples of different magmatic facies known in Tagmout. These samples are taken at the surface and depth levels at the core drilling out in the area.

Only the primary mineral parageneses of the rocks will be described in this section.

\section{Olivine gabbronorite:}

The study of this facies shows that it is a well crystallized dark rock, has a granular texture.It is composed of a mineral paragenesis formed by the plagioclases, it is often present in large acicular laths recognizable by their polarized texture and their polysynthetic twin. The basicity of this mineral shows that the percentage of Anorthite is a Labrador plagioclase type (50$55 \%$ of An); pyroxene, It is present either in the autocorne or in the xenomorphic range filling the interstitial spaces between the plagioclase laths. We, thus, distinguish the clinopyroxenes and orthopyroxenes; the olivines, They are very abundant with automorphic minerals which are rounded or globular with cracks in iddingsites that are filled with the oxides resulting from the alteration of the mineral. It is found in small corroded or blunted granules in plagioclases and pyroxenes. Some crystals present serpentine alteration, biotite, it is present in large slats, in aggregates and lamellae which are often associated with opaque minerals.

Incidentally, opaque minerals, zircons and apatite are common. (Fig. 5 photos B).

\section{Quartz monzogabbro:}

The macroscopic study of this facies shows that it is a facies of mesocratic color, has a well-crystallized granular texture. On the ground, it changes into a ball and occupies the central part of the gabbroic massive. The microscopic study of this rock has made it possible to highlight a paragenesis that is composed mainly by pyroxene which is often automorphic, it is an augite type and which is present only in clinopyroxene. They are largely altered in brown amphiboles; amphibole; potassic feldspars; quartz and biotite. The plagioclase with a basicity of mineral which shows that it is an andesine plagioclase (An: 30-40).

Incidentally, opaque minerals and apatite are present (Fig. 5 photo D).

\section{Quartz monzodiorite:}

It is a porphyry facies. It is well crystallized of mesocratic color, has a granular texture. The microscopic observation of the quartz monzodiorite shows that it is formed by k-feldspars with carlsbad twins and plagioclases with polysynthetic twins on which develops a phyllitic alteration. Their basicity shows that it is about an oligoclase plagioclase (An: 10-20), quartz with xenomorphic crystals, amphibole of green hornblende type and 
pyroxenes of the clinopyroxenes types. The minerals of zircon and apatite are incidentally present in the rock. (Figure 5 photo $\mathrm{C}$ ).

\section{Granodiorite :}

The macroscopic study shows that granodiorite is a light-colored facies and a micro-granular texture with all the minerals well crystallized. The microscopic observation of this rock made it possible to demonstrate a mineral paragenesis formed by plagioclase with polysynthetic twins; pyroxene, which is less abundant, it is a clinopyroxene type. It sometimes shows the sections with double cleavage showing the cleavage making a $90^{\circ}$ angle characteristic of the mineral; amphibole that looks more abundant in the form of aggregates of sub-automorphic crystals, quartz, which appears in the form of small xenomorphic and interstitial crystals and k-feldspar that shows simple twins characteristics of Carlsbad type ( Fig. 5 photo A). Incidentally, the minerals Apatite, Zircon and Opaque minerals are present.

\section{Granite:}

The mineralogical association of granitic facies is represented by quartz, K-feldspar, which sometimes shows the exsolution of perthite, plagioclase with polysynthetic twins which are often affected by phyllitic alteration (sericite) and rare biotite(Fig.5 photo $\mathrm{G}$ ).

\section{Microgranite:}

The microgranite of Tagmout is characterized by a pink color and a microgranular texture which is well crystallized and rich in k- feldspar. Microscopic observation of the facies revealed a mineral association essentially formed by:

-Quartz with xenomorphics phenocrystals,

- The k- feldspar, which is often in crystals with a dirty, perthitic aspect and a simple twin from Carlsbad,

-Plagioclase, which is less abundant, finely twinned, sometimes polysynthetic twin sand often obliterated by a phyllitic alteration to sericite and chlorite. (Fig5. photo F).

Incidentally, the rock has opaque minerals and sphenes.

\section{Dolerite:}

It is a volcanic facies with a dark color and a microlitic texture. This facies looks fresh according to an alteration view. Microscopically, it shows a doleritic texture which is typical of this facies. The mesostasis is essentially composed of microlite of plagioclases; pyroxenes are rare and present themselves as small relics. They are largely transformed into amphibole and carbonates; the amphibole is much more abundant. It is a hornblende type, the majority of which are derived from the alteration of pyroxenes (Fig 5. photo E). 


\section{Volcano-Sedimentary Facies:}

It is a facies with a red chocolate rhyolitic appearance and with a very fine matrix of volcanic nature. The figured elements have differents sizes and correspond to the residues of conglomerates and red sandstones. Microscopically, this facies shows many grains of quartz and k-feldspar bathed in a matrix of volcanic nature (Fig. 5 photo $\mathrm{H}$ ).

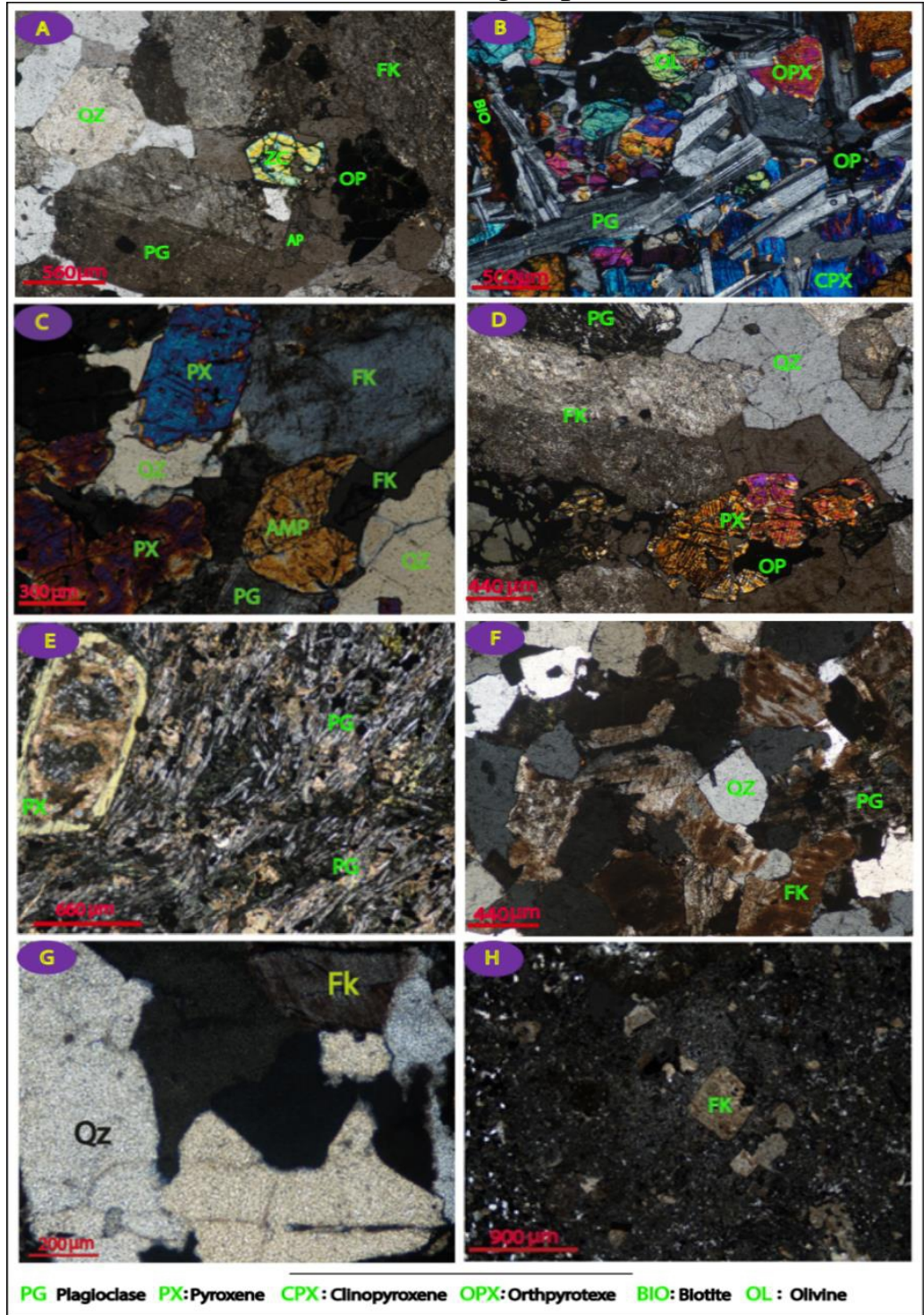

Fig. 5: photos showing the mineral paragenesis of the different geological rocks of Tagmout

\section{Conclusion}

The Tagmout deposit is located in the Eastern Anti-Atlas. It contains $\mathrm{Cu}-\mathrm{Ag}$ mineralization that is embedded in magmatic rocks which are 
essentially intrusive nature of various facies . The petro-mineralogical study of these facies as well as the detailed mapping (at 1/1000) made it possible to distinguish the facies ranging from an olivine gabbronorite to granite. The mutual relationship between Tagmout intrusive formations suggested that the plutonic formations of this massive were derived from the same magma by fractional crystallization in a magmatic chamber.

\section{References:}

1. Ezzouhairi, H., 1989. Etude pétrographique, géochimique et structurale des formations plutoniques du Précambrien II de la boutonnière de Bou Skour (Saghro occidental, Anti Atlas, Maroc). Thèse Doct. 3ème cycle. Univ. Cadi Ayad, Marrakech, 210p.

2. BENZIANE F, YAZIDI A., WALSH G.J., YAZIDI M., SAADANE A., STONE B.D., EL FAHSSI A., EJJAOUANI H. (2008) : Mémoire éxplicatif de la carte géologique du Maroc au 1/50 000, feuille Qal'at Mgouna. Notes et Mém. Serv. Géol. Maroc, n 468 bis, 140 p.

3. Benziane, F., 2007. Lithostratigraphie et évolution géodynamique de l'Anti-Atlas (Maroc) du Paléoprotérozoïque au Néoprotérozoïque : exemple de la boutonnière de Tagragra da Tata et du Jbel Saghro. Thèse d'Etat, Université de Savoie.

4. Gasquet, D., Ennih, N., Liégeois, J.P., Soulaimani, A., Michard, A., 2008. The Pan African Belt, in Continental Evolution: The Geology of Morocco. Lecture Notes in Earth Sciences,vol.116.SpringerVerlagPublishing,Berlin,pp.33-64.

5. Gasquet, D., Levresse, G., Cheilletz, A., Azizi-Samir, M.R., Mouttaqi, A., 2005. Contribution to a geodynamic reconstruction of the Anti-Atlas (Morocco) during Pan-African times with the emphasis on inversion tectonics and metallogenic activity at the Precambrian-Cambriantransition.Precamb.Res.140,157-182.

6. Gasquet, D., Roger, J., Chalot-Prat, F., Hassenforder, B., Baudin, T., Chèvremont, Benlakhdim, A., Razin, P., 2001. Notice explicative, carte géologique Maroc (1/50000), feuille de Tamazrar. MEM/BRGM, p78

7. Ighid, L., Saquaque, A., Reuber, I., 1989. Plutons syn-cinématiques et la déformation panafricaine majeure dans le Saghro oriental (boutonnière d'Imiter, Anti-Atlas, Maroc). Comptes Rendus de l'Académie des Sciences de Paris 309 (II): 615-620.

8. Mokhtari, A., 1993. Nouvelles données et interprétations du massive basique de Tagmout (Jbel Saghro, Anti-Atlas, Maroc): relations avec les granitoïdes associés. Thèse de doctorat 3ème cycle, Nancy I, 251 p. 
9. Walsh, G.J., Benziane, F., Aleinikoff, J.N., Harrison, R.W., Yazidi, A., Burton, W.C., Quick, J.E., Saadane, A., 2012. Neoproterozoic tectonic evolution of the Jebel Saghro and Bou Azzer-El Graara inliers, eastern and central Anti-Atlas, Morocco. Precambr. Res. 216-219, $23-62$.

10. Walsh, G.J., Burton, W.C., El Fahssi, A., Benziane, F., Yazidi, A., Yazidi, M., Saadane, A., Aleinikoff, J.N., Ejjouani, H., 2007. Carte géologique du Maroc au 1/50000, feuille Bouskour. Notes et Mém., Serv. Géol. Maroc, $\mathrm{n}^{\circ} 496$.

11. Walsh, G. J., Aleinikoff, J. N., Benziane, F., Yazidi, A., Armstrong, T. R., 2002. U-Pb zircon geochronology of the Paleoproterozoic Tagrara de Tata inlier and it Neoproterozoic cover, Western AntiAtlas, Morocco. Precambrian Research 117: 1-20. 